\title{
STATUS KAWASAN KONSERVASI PERIKANAN PERAIRAN UMUM DARATAN DI BEBERAPA LOKASI PULAU SUMATERA
}

\author{
Khairul Amri'1), Ali Suman'), dan Chairulwan Umar') \\ 1) Peneliti pada Pusat Riset Perikanan Tangkap, Ancol-Jakarta \\ 2) Peneliti pada Balai Riset Perikanan Perairan Umum, Mariana-Palembang \\ Teregistrasi I tanggal: 24 Pebruari 2009; Diterima setelah perbaikan tanggal: 1 Mei 2009;
}

Disetujui terbit tanggal: 28 Mei 2009

\begin{abstract}
ABSTRAK
Penelitian kondisi kawasan konservasi perikanan di beberapa lokasi telah dilakukan mulai bulan Maret-Agustus 2007. Untuk Pulau Sumatera penelitian dilakukan di Propinsi Nangroeh Aceh Darussalam, Sumatera Utara, Riau, dan Jambi. Tujuan Penelitian ini adalah untuk mengevaluasi kondisi kawasan konservasi perikanan perairan umum, khususnya suaka perikanan yang ada. Penelitian ini dilakukan dengan metode survei lapangan, pada lokasi yang ditentukan dengan sengaja atau dipilih (purposive) di kawasan konservasi perikanan Danau Laut Tawar, Propinsi Nangroeh Aceh Darusalam, Sumatera Utara, Riau, dan Jambi. Di samping itu, juga dilakukan desk study, studi literatur, dan wawancara dengan petugas Dinas Perikanan Tingkat I dan II serta nelayan sekitar kawasan konservasi. Data yang dikumpulkan dalam penelitian ini, di antaranya jenis ikan, sistem pengelolaan, tipe perairan, dan kondisi sumber daya perikanan. Hasil penelitian menunjukkan bahwa kawasan konservasi di Sumatera sangat beragam dan pada umumnya belum didukung dengan perangkat hukum sebagai dasar pembentukkan. Namun demikian, upaya penetapan atau penyiapan calon kawasan konservasi sudah dilakukan. Kawasan konservasi yang dikelola secara adat oleh kelompok masyarakat seperti di Propinsi Riau (Danau Bakuok) berhasil baik sekali dan di Propinsi Jambi juga masuk katagori baik.
\end{abstract}

\section{KATAKUNCI: perairan umum daratan, konservasi perikanan, Pulau Sumatera}

\section{PENDAHULUAN}

Pulau Sumatera merupakan salah satu pulau yang mempunyai potensi perairan dan sumber daya perikanan perairan umum yang besar. Dari total 13,85 juta ha luas total perairan umum daratan (air tawar) di Indonesia, sekitar 23\% terdapat di Sumatera (Sarnita et al., 1995). Berdasarkan pada data hasil tangkapan ikan, di beberapa lokasi di Indonesia menunjukkan indikasi terjadinya penurunan produksi perikanan perairan umum. Penurunan ini diduga terjadi akibat pola penangkapan ikan yang tidak terkendali tanpa memperhatikan keberlangsungan hidup ikanikan tersebut, serta penurunan kualitas lingkungan perairan sebagai akibat dari aktivitas manusia dalam memanfaatkan sumber daya lingkungan sekitar. Sehingga upaya mengendalikan dan memulihkan kondisi sumber daya perikanan perairan umum yakni upaya pelestarian sumber daya dipandang sebagai langkah yang sangat penting untuk dilakukan secara intensif.

Pelestarian sumber daya perikanan perairan umum ditujukan untuk pengendalian pemanfaatan sumber daya ikan dan lingkungan perairan umum agar berfungsi memberikan manfaat sebesar-besarnya bagi kesejahteraan masyarakat, baik generasi sekarang maupun yang akan datang secara terus-menerus. Upaya pengelolaan perairan umum, di antaranya melakukan pengaturan penangkapan serta memperbanyak suaka perikanan (protected area) yang telah ada. Suaka perikanan didefinisikan sebagai suatu luas tertentu perairan darat atau perairan bahari yang mempunyai bagian tertentu yang ikannya tidak boleh ditangkap, yang dikelola untuk melestarikan dan meningkatkan produksi berdasarkan pada stok alami setempat untuk kesejahteraan masyarakat setempat (Anonim, Undang-undang RI No.31 tahun 2004 tentang Perikanan Pasal 7 ayat 1q). Saat ini suaka perikanan perairan umum daratan pada umumnya terdapat di sungai, danau atau waduk, rawa atau rawa banjiran, situ atau bagian dari sungai, danau atau waduk, dan rawa atau situ tersebut.

Suaka perikanan dapat berfungsi sebagai tempat konservasi sumber daya perikanan, melindungi ikan yang sudah langka, sumber plasma nutfah perikanan, dan secara alami sebagai sumber benih perairan sekitarnya. Suaka produksi ikan di perairan sungai dan rawa banjiran dapat dikembangkan melalui penutupan penangkapan ikan sepanjang tahun atau selama musim tertentu, atau melalui pelarangan penggunaan alat tertentu tergantung pada tujuan dan faktor hidrologi setempat. Suaka produksi ikan di lokasi yang dikelola secara efektif ternyata telah meningkatkan jumlah ikan yang memijah setiap tahunnya, mencegah kepunahan jenis-jenis ikan lokal, dan meningkatkan hasil tangkapan ikan setempat. 
Namun demikian, suaka produksi ikan bukan satusatunya cara pengelolaan perikanan perairan sungai dan rawa banjiran (Hoggarth et al., 1994).

Saat ini di Sumatera terdapat beberapa kawasan suaka perikanan baik yang telah ditetapkan oleh pemerintah maupun yang ditetapkan dan dikelola secara hukum adat oleh masyarakat setempat. Permasalahan suaka perikanan di Indonesia pada umumnya yaitu jumlahnya kurang bila dibanding luasan perairan, secara bioekologi kurang memenuhi persyaratan, banyak mengalami pendangkalan dan terancam gulma air yang tidak terkendali (Sarnita et al., 1995).

Terkait dengan kondisi tersebut, perlu dilakukan suatu penelitian tentang status suaka perikanan yang terdapat di Sumatera, sehingga dapat diketahui data dan informasi yang akurat dan menyeluruh mengenai kondisi suaka perikanan yang ada. Untuk mengetahui apakah suaka perikanan dapat berfungsi atau tidak sebagai daerah penyangga sumber daya perikanan di perairan sekitarnya, indikator yang paling menonjol adalah jenis ikan yang ada dalam suaka menyebar ataupun tidak di sekitar perairan sekitarnya. Bila suaka tersebut berfungsi, saat musim banjir (air besar) anakkan ataupun induk ikan yang ada dalam suaka menyebar ke perairan di sekitarnya. Tulisan ini menguraikan bagaimana kondisi kawasan suaka perikanan di beberapa propinsi di Sumatera.

\section{BAHAN DAN METODE}

Penelitian ini dilakukan di beberapa propinsi yang memiliki kawasan konservasi di Sumatera, yakni Nangroeh Aceh Darussalam, Sumatera Utara, Riau, dan Jambi. Penelitian ini dilakukan dengan metode survei lapangan melalui kunjungan dan wawancara atau diskusi dengan aparat terkait (Dinas Perikanan dan Kelautan Propinsi dan nelayan) serta dilengkapi dengan data sekunder melalui studi pustaka dari beberapa hasil laporan yang sudah ada. Teknik survei melalui pengamatan dengan melakukan verifikasi langsung ke wilayah suaka perikanan sesuai dengan kriteria evaluasi yang dikembangkan Hartoto et al. (1998).

Lokasi pengamatan kondisi suaka perikanan sebagai berikut Danau Laut Tawar di Kabupaten Aceh Tengah (Nangroeh Aceh Darussalam), Danau Toba (Sumatera Utara), Danau Bakuok di Bangkinang, Kabupaten Kampar (Riau), serta di Danau Arang dan Danau Lamo (Jambi).

Untuk mendukung data primer terutama untuk menganalisis keragaan sumber daya ikan dilakukan juga wawancara dengan nelayan. Selanjutnya, pengumpulan data sekunder dari Dinas Perikanan dan Kelautan setempat.

Data dan informasi yang diperoleh dikompilasi dengan metode desk study melalui pertemuan dan diskusi. Analisis status suaka perikanan dilakukan dengan analisis input, proses, output, dan dampak).

\section{HASIL DAN BAHASAN}

Hasil survei dan kajian mengenai kondisi kawasan konservasi perikanan yang dilakukan pada beberapa lokasi di Pulau Sumatera menunjukkan kondisi yang sangat beragam.

\section{Danau Laut Tawar (Nangroeh Aceh Darussalam)}

\section{Kondisi Umum}

Danau Laut Tawar (Lut Tawar) merupakan salah satu perairan yang memiliki potensi paling tinggi di Propinsi Nangroeh Aceh Darussalam. Danau yang terletak di bagian timur ibukota Kabupaten Aceh Tengah ini memiliki luas 5.472 ha dan kedalaman ratarata $51,13 \mathrm{~m}$. Di sepanjang ruas jalan sekeling danau terdapat 28 desa dan kelurahan yang masuk ke dalam wilayah kecamatan Lut Tawar, Kecamatan Kebayakan dan Kecamatan Bintang. Aliran air permukaan atau sungai yang menuju ke Danau Lut Tawar berjumlah 25 buah yang berasal dari 18 daerah hulu atau kawasan tangkap dengan debit air bervariasi dari 11$2.554 \mathrm{~L}$ per detik. Debit air keluar tercatat $5.664 \mathrm{~L}$ per detik dan tercatat air hilang $975 \mathrm{~L}$ yang diduga akibat transpirasi tumbuhan air dan penguapan. Volume air danau secara keseluruhan adalah $2.537 .884 \mathrm{~m}^{3}$ dengan kondisi fisika kimia seperti tersaji pada Tabel 1.

Dari hasil studi di perairan Danau Laut Tawar terdapat 13 jenis ikan seperti tersaji pada Tabel 2. Ikan depik (Rasbora tawarensis), eyas (Rasbora sp.), dan relo (Rasbora sp.) merupakan jenis ikan endemik yang terdapat di Danau Laut Tawar. Hasil tangkapan ikan depik, relo, dan eyas berfluktuasi menurut musim. Pada saat bulan terang, hasil tangkapan lebih kecil daripada keadaan bulan gelap. Ikan depik, relo, dan eyas ini banyak tertangkap pada bulan Agustus dan September dan kemudian kelimpahannya menurun pada bulan Pebruari. Secara umum, hasil tangkapan ikan depik, eyas, dan relo cenderung menunjukkan penurunan jika dibandingkan dengan tahun sebelumnya. Ikan mas (Cyprinus carpio), mujair (Oreochromis mossambicus), nila (O. niloticus), dan grass carp (Ctenoparyngodon idella) adalah ikan hasil introduksi. Ikan mas banyak tertangkap pada bulan 
Tabel 1.

Kualitas perairan Danau Laut Tawar, Aceh Tengah

\begin{tabular}{clcccccc}
\hline No. & \multicolumn{1}{c}{ Parameter } & Satuan & Nilai & No. & Parameter & Satuan & Nilai \\
\hline & Parameter fisika & & & 2. & COD & $\mathrm{mg} / \mathrm{L}$ & - \\
1. & Suhu & $\circ \mathrm{C}$ & 20,82 & 3. & BOD & $\mathrm{mg} / \mathrm{L}$ & 0,80 \\
2. & Debit air & liter & 2254 & 4. & Nitrat & $\mathrm{mg} / \mathrm{L}$ & 0,032 \\
3. & Kecerahan air & meter & 2,07 & 5. & Nitrit & $\mathrm{mg} / \mathrm{L}$ & 0,002 \\
4. & DHL & $\mu S$ & 191,684 & 6. & Fosfat & $\mathrm{mg} / \mathrm{L}$ & 0,51 \\
5. & Kedalaman & meter & 51,13 & 7. & Kalium & $\mathrm{mg} / \mathrm{L}$ & 1,89 \\
& Parameter kimia & & & 8. & $\mathrm{PH}$ & - & 8,23 \\
1. & DO & $\mathrm{mg} / \mathrm{L}$ & 5,94 & & & & \\
\hline
\end{tabular}

Sumber: Dinas Perikanan Aceh Tengah

Tabel 2. Jenis-jenis ikan yang tertangkap di perairan Danau Laut Tawar, Aceh Tengah

\begin{tabular}{rlll}
\hline No. & \multicolumn{1}{c}{ Nama Indonesia } & \multicolumn{1}{c}{ Nama lokal } & \multicolumn{1}{c}{ Nama ilmiah } \\
\hline 1. & Mas & Bawal & Cyprinus carpio \\
2. & - & Peres & Osteochilus hasselti \\
3. & Mujair & Mujaer & Oreochromis mossambicus \\
4. & Nila & Nila & Oreochromis niloticus \\
5. & Gabus & Gabus & Channa striatus \\
6. & Grass carp & Grass carp & Ctenoparyngodon idella \\
7. & Lele & Lele & Clarias batrachus \\
8. & - & Pedih & Neolissochilus tambroides \\
9. & - & Jojolong & Macrochyrichthys macrohyrus \\
10. & - & Depik & Rasbora tawarensis \\
11. & - & Relo & Rasbora sp. \\
12. & - & Eyas & Rasbora sp. \\
13. & - & Kepras & Rasbora sumatrana \\
\hline
\end{tabular}

Sumber: Dinas Perikanan Aceh Tengah
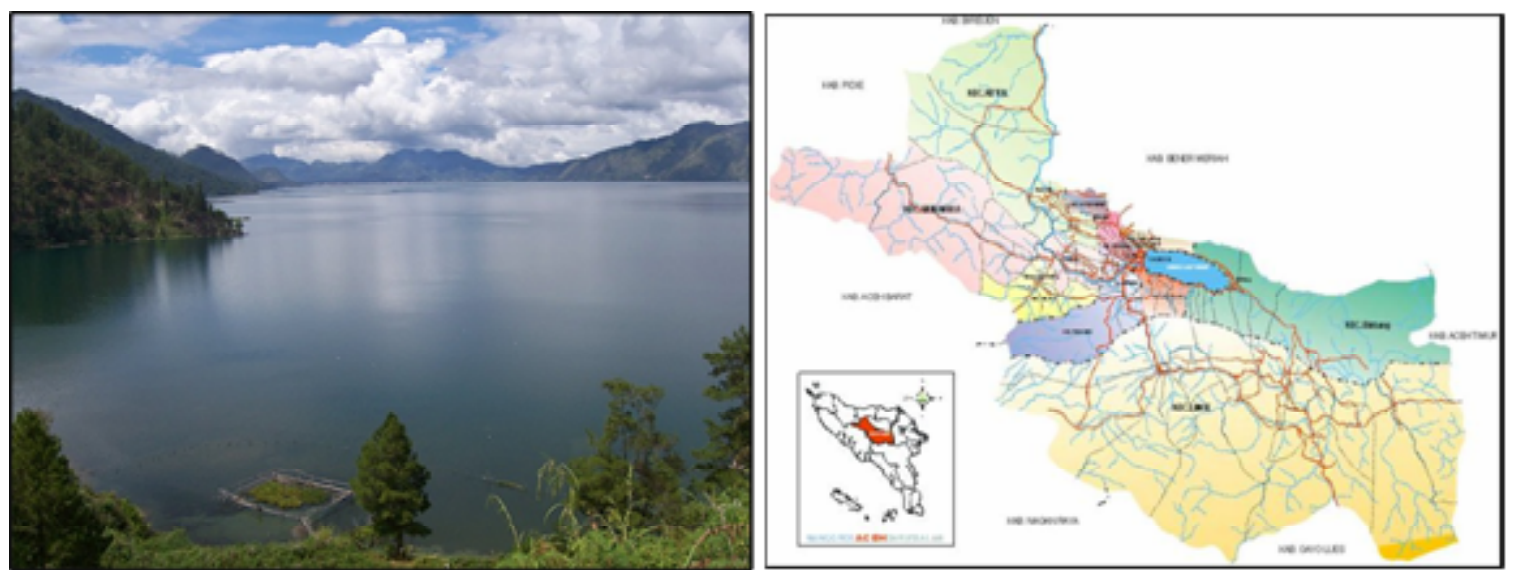

Gambar 1. Kondisi Danau Laut Tawar di Nangroeh Aceh Darussalam.

Pebruari, sedangkan pada bulan Agustus dan September kelimpahannya relatif sama. Kondisi Danau Laut Tawar di Nangroeh Aceh Darussalam ditampilkan pada Gambar 1.

\section{Pengelolaan Suaka Perikanan}

Dari hasil verifikasi dan survei di perairan Danau Laut Tawar, Aceh terlihat program pemerintah untuk mengelola perairan tersebut jauh dari memadai. Sampai saat ini aturan pengelolaan sumber daya ikan di Danau Laut Tawar baru berupa Peraturan Pemerintah Daerah No.5 pada Tahun 1999 yaitu tentang alat tangkap yang boleh digunakan serta Pemerintah Daerah No.39 Tahun 2001 tentang garis sempadan dan pemanfaatan daerah pengusahaan tepi Danau Lut Tawar, Lot Kala Boom, Kabupaten Aceh Tengah. Aspek pengelolaan lainnya adalah adanya pemacuan stok ikan yang dilakukan oleh Dinas Perikanan dan Peternakan Kabupaten Aceh Tengah bekerjasama dengan Dinas Kelautan dan Perikanan Propinsi Nangroeh Aceh Darussalam. Selain itu 
pengawasan pengelolaan danau juga di dukung oleh masyarakat sekitar danau. Masyarakat tersebut tergabung dalam organisasi yang bernama Badan Laut Tawar Takengon (Badan Lantak). Badan Lantak ini ikut serta dan berperan aktif dalam kelestarian Danau Lut Tawar melalui kegiatan pengawasan dan perlindungan sumber daya perikanan Danau Lut Tawar. Selain itu Badan Lantak juga memelihara dan menegakkan kebiasaan atau adat istiadat melaut serta menyelesaikan persoalan-persoalan terhadap perlanggaran ketentuan adat yang berlaku.

Untuk kepentingan suaka perikanan sampai saat ini belum ada wilayah yang sudah ditetapkan bagi tujuan tersebut. Konsekuensi logis yang tejadi saat ini adalah makin menurunnya stok ikan endemik berupa ikan depik. Ikan tersebut memijah di sekitar muara-muara sungai yang masuk ke Danau Laut Tawar, dan wilayah ini menjadi wilayah yang tertutup untuk penangkapan. Namun yang terjadi saat ini adalah daerah tersebut justru menjadi pusat penangkapan ikan depik bagi nelayan di danau tersebut, dan akibat selanjutnya ikan-ikan tersebut tidak dapat melakukan pembaruan populasi. Dampak dari hal tersebut sudah mulai terasa dengan makin sulitnya tertangkap ikan depik di perairan tersebut, dan apabila kondisi ini berlangsung dalam jangka panjang, maka akan mengakibatkan punahnya ikan tersebut dari Danau Laut Tawar. Hal ini sudah mulai disadari oleh Pemerintah Daerah Kabupaten Aceh Tengah dan pada saat ini sudah mulai diproyeksikan wilayah-wilayah yang akan menjadi daerah suaka perikanan. Pemerintah Daerah merencanakan sekitar 117,188 ha wilayah danau atau sekitar $1,5 \%$ dari luas dana keseluruhan akan menjadi wilayah suaka perikanan terutama di muara-muara sungai yang ada di sekitar Danau Laut Tawar.

\section{Status Suaka Perikanan}

Hasil verifikasi yang dilakukan di perairan Danau Laut Tawar menunjukkan bahwa sampai saat ini belum ada suatu wilayah perairan Danau Laut Tawar yang secara resmi ditetapkan oleh pemerintah Propinsi dan Kabupaten sebagai daerah suaka perikanan. Dari pantauan terhadap sejumlah wilayah di perairan Danau Laut Tawar terlihat wilayah perairan yang layak untuk suaka perikanan adalah daerah Kala Bintang, Teluk Suyen, Teluk Bewang, dan Teluk Kelito. Hal ini mengingat wilayah-wilayah tersebut merupakan daerah pemijahan bagi ikan endemik Danau Laut Tawar yaitu ikan depik. Ikan ini mulai melakukan pemijahan di keempat wilayah tersebut antara bulan Juni-September, di mana mulai terjadi awal musim hujan. Di satu sisi, ikan depik ini dibiarkan untuk melakukan pemijahan bagi kesinambungan hidupnya, tetapi di sisi lainnya justru puncak musim penangkapan dilakukan pada waktu yang sama di wilayah pemijahan tersebut. Konsekuensi logisnya dalam jangka panjang akan mengakibatkan terjadinya penurunan populasi ikan depik atau bahkan dapat punah, karena tidak diberi kesempatan untuk melakukan pembaruan populasi. Penurunan populasi tersebut juga diperparah oleh degradasi lingkungan yang dilakukan oleh PT. Kertas Kraft Aceh. Perusahaan ini telah membuka jalur jalan di sekeliling Danau Laut Tawar untuk kepentingan pengangkutan kayu sebagai bahan baku produksinya, dan ini berdampak kepada penggundulan hutan di sekeliling danau. Akibat selanjutnya pada setiap musim hujan, lumpur yang tergerus di sekitar danau terutama untuk daerah pemijahan ikan depik akan menyebabkan kekeruhan di daerah tersebut. Dampaknya ikan depik tersebut kesulitan mencari habitat untuk pemijahan yang mensyaratkan kejernihan air di pinggir danau yang ada muara sungainya. Dengan demikian, dapat dikatakan bahwa kelestarian sumber daya ikan endemik berupa ikan depik di perairan Danau Laut Tawar sudah terancam dan dalam jangka panjang dapat terancam punah apabila tidak segera dilakukan usaha-usaha pengelolaan yang rasional.

Kebijakan Pemerintah Daerah yang belum menetapkan suaka perikanan secara resmi di wilayah ini menunjukkan bahwa pemerintah setempat belum memberi perhatian yang besar pada kelestarian sumber daya ikan di Danau Laut Tawar. Status pemanfaatan yang sudah menunjukkan terjadinya penurunan produksi pada akhir-akhir ini terutama bagi ikan depik mengharuskan semua pihak untuk mendorong secepatnya penetapan suaka perikanan di wilayah ini, dengan demikian kelestarian sumber daya ikan dapat terjaga dengan baik.

Dari hasil verifikasi dan survei yang dilakukan sebelumnya pada bulan Mei 2007 di perairan Danau Laut Tawar, Aceh terlihat program pemerintah untuk mengelola perairan tersebut jauh dari memadai. Aturan pengelolaan sumber daya ikan di Danau Laut Tawar baru berupa Peraturan Pemerintah Daerah No.5 Tahun 1999 tentang alat tangkap yang boleh digunakan serta Peraturan Daerah No.39 Tahun 2001 tentang garis sempadan dan pemanfaatan daerah pengusahaan tepi Danau Lut Tawar, Lot Kala Boom, Kabupaten Aceh Tengah. Aspek pengelolaan lainnya adalah adanya pemacuan stok ikan yang dilakukan oleh Dinas Perikanan dan Peternakkan Kabupaten Aceh Tengah bekerjasama dengan Dinas Kelautan dan Perikanan Propinsi Nangroeh Aceh Darussalam. 

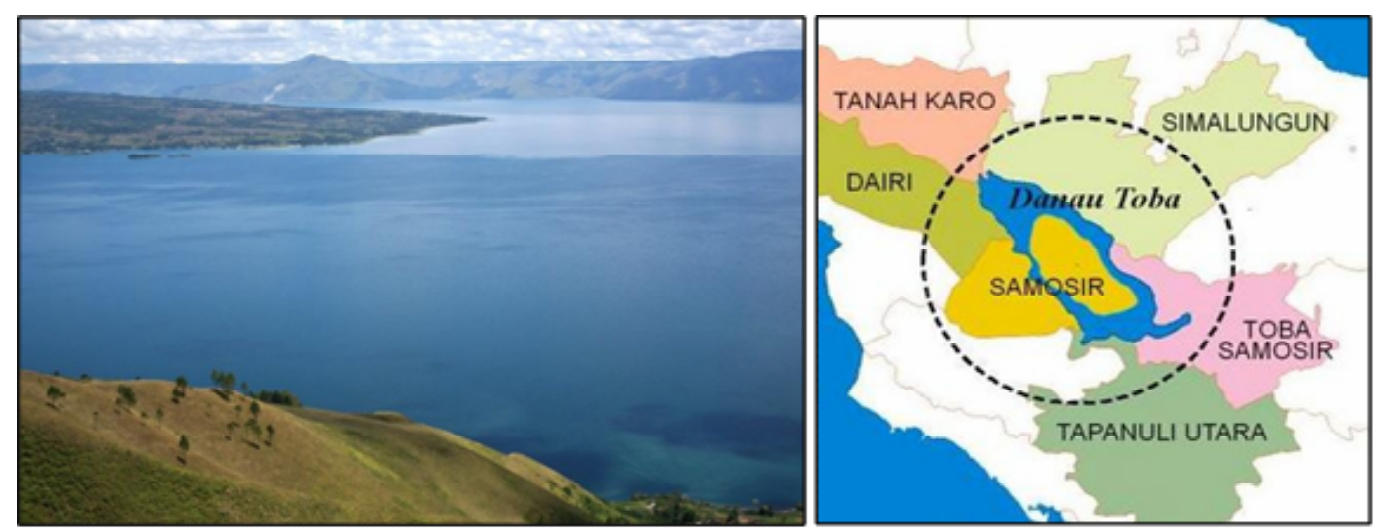

Gambar 2. Danau Toba di Sumatera Utara.
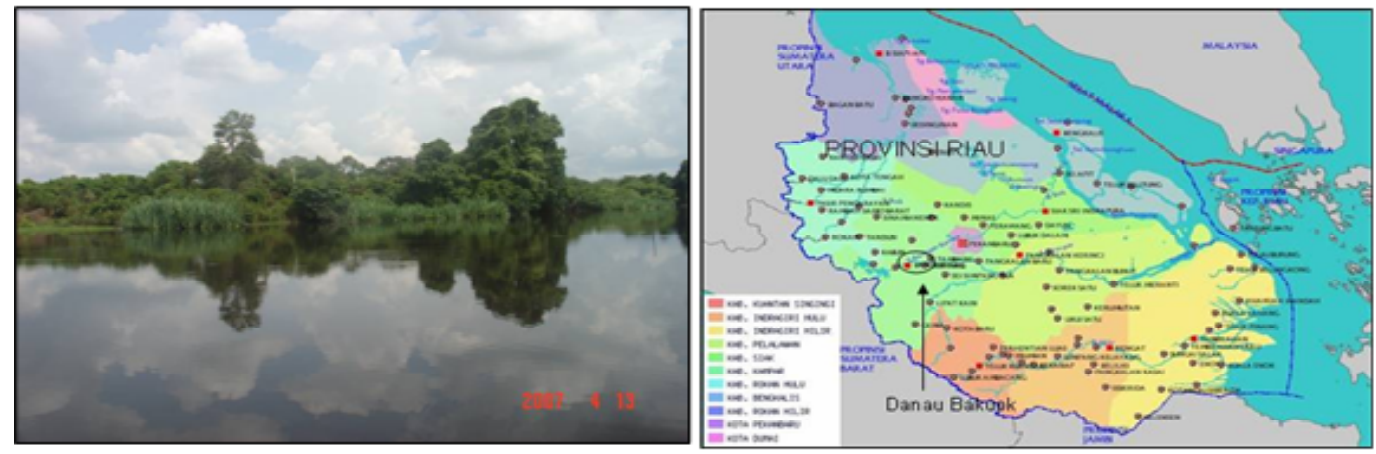

Gambar 3. Danau Bakuok, Bangkinang (Riau).

\section{Danau Toba (Sumatera Utara)}

\section{Kondisi Umum}

Danau Toba termasuk tipe danau vulkanik dengan tingkat kesuburan perairan yang sangat rendah (oligotrofik); volume air $240 \mathrm{~km}^{3}$, kecerahan air (water transparency) mencapai $22 \mathrm{~m}$ (Ruttner, 1930). Danau Toba dihuni oleh sedikitnya 18 jenis ikan, termasuk jenis-jenis ikan asli maupun hasil introduksi. Namun beberapa tahun belakangan ini yang banyak tertangkap adalah ikan batak (Noulosilus sp.), hampal (Hampala macrolepidota), mujair, nila, gabus (Channa striata), betutu (Oxyeleotris marmorata), lele (Clarias batrachus), mas, tawes (Barbodes gonionotus), betok (Anabas testudineus), dan bilih (Mystacoleucus padangensis). Jenis ikan yang saat ini dominan adalah ikan mujair, bilih, dan mas. Ketiga jenis ikan tersebut merupakan jenis-jenis ikan introduksi yang masingmasing dimasukkan ke Danau Toba pada tahun 1940 dan 1937, kecuali ikan bilih (Sarnita, 1999). Upaya introduksi ikan mujair dan mas dalam perkembangannya secara tidak langsung telah menekan populasi ikan asli yaitu ikan batak yang oleh masyarakat setempat disebut ihan. Jenis ikan ini sangat mahal harganya dan sering disajikan dalam upacara-upacara ritual adat masyarakat batak (Kartamihardja, 1987; Tjahjo et al., 1998). Potensi produksi ikan berdasarkan pada hasil pengukuran produksi primer berkisar antara 2.519 dan 7.309 ton per tahun (Krismono \& Sarnita, 2003). Hasil monitoring terhadap hasil tangkapan ikan harian menunjukkan bahwa produksi tangkapan ikan di danau ini pada tahun 2005 mencapai 4.462 ton. Berarti tingkat pemanfaatannya sudah mencapai $61 \%$. Salah satu bagian panorama Danau Toba di Sumatera Utara ditampilkan pada Gambar 2.

Usaha penangkapan ikan di Danau Toba beberapa tahun belakangan ini mengalami penurunan produksi. Produksi tangkapan ikan yang pada tahun 1996 mencapai 1.303 ton mengalami penurunan terus sehingga pada tahun 2001 produksi tersebut hanya mencapai 1.150 ton (Anonimus, 2003). Penurunan produksi tersebut erat kaitannya dengan penggundulan hutan di daerah tangkapan air (catchment area) serta pola pemanfaatan yang kurang memperhatikan aspek kelestarian sumber daya ikan. Satu hal yang menarik perhatian adalah kehadiran ikan betutu dan bilih. Ikan betutu diintroduksikan dari Waduk Jatiluhur pada tahun 1998, sedangkan ikan bilih diintroduksikan dari Danau Singkarak pada tahun 2003. Kini ikan bilih telah berkembang dan memenuhi perairan Danau Toba, sehingga nelayan mulai menyadari bahwa hasil tangkapannya meningkat kembali sejak adanya ikan bilih. 


\section{Keadaan Suaka Perikanan}

Hasil evaluasi sementara yang dilakukan di perairan Danau Toba menunjukkan bahwa sampai saat ini belum ada suatu wilayah perairan Danau Toba yang secara resmi ditetapkan oleh pemerintah Propinsi dan Kabupaten sebagai daerah suaka perikanan. Dari pantauan terhadap sejumlah suaka perikanan yang telah diproyeksikan oleh Pemerintah Daerah setempat menunjukkan bahwa daerah Bakkara, Tongging, dan Balige layak untuk ditetapkan sebagai daerah suaka perikanan. Selain itu daerah yang cocok dijadikan sebagai suaka perikanan khususnya ikan bilih adalah muara-muara sungai untuk melindungi ikan bilih yang akan memijah seperti Sungai Sipangolu (Bakara), Sungai Sipiso-piso (Tongging), Sungai Sisodang (Tomok), dan Sungai Naborsahan (Ajibata) (Parapat) dan sungai-sungai kecil yang banyak terdapat di Desa Silalahi I dan II hingga dekat lokasi pembangkit listrik tenaga air Renum.

Kebijakan Pemerintah Daerah yang belum menetapkan suaka perikanan secara resmi di wilayah ini menunjukkan bahwa pemerintah setempat belum memberi perhatian yang besar pada kelestarian sumber daya ikan di Danau Toba. Status pemanfaatan yang sudah menunjukkan terjadinya penurunan produksi pada akhir-akhir ini semua pihak untuk mendorong secepatnya penetapan suaka perikanan di wilayah ini, dengan demikian kelestarian sumber daya ikan dapat terjaga dengan baik. Oleh karena perairan Danau Toba secara administratif termasuk ke dalam 8 kabupaten (Tapanuli Utara, Toba Samosir, Humbang Hasundutan, Samosir, Simalungun, Karo, Dairi, dan Pakpak Barat), maka peraturan penetapan suaka perikanan tersebut ditetapkan berdasarkan pada Peraturan Daerah pada tingkat propinsi Sumatera Utara. Hal ini sangat penting sehingga Peraturan Daerah di tingkat kabupaten dapat mengacu pada Peraturan Daerah di tingkat propinsi.

\section{Danau Bakuok (RIAU)}

\section{Kondisi Umum}

Danau Bakuok terletak di Desa Aursati, Kecamatan Tambang, Kabupaten Kampar dengan posisi geografis 00.21.47.3 LU dan 101.15.57.6 BT. Danau Bakuok berukuran kurang lebih $1.000 \mathrm{~m} \times 100$ $\mathrm{m}$, dan merupakan jenis danau oxbowyang terbentuk melalui pemutusan aliran Sungai Kampar pada lokasi persis di Kecamatan Tambang. Danau ini ditetapkan sebagai suaka perikanan yang dijalankan berdasarkan pada sistem atau hukum adat.
Danau Bakuok memiliki keragaman jenis dan produktivitas yang cukup besar. Di samping dijumpai berbagai jenis ikan ekonomis lokal juga memiliki jumlah produksi yang tinggi. Jenis-jenis ikan yang terdapat di Danau Bakuok adalah ikan patin (Pangasius jambal), baung (Mystus nemurus), dan ikan air tawar lainnya termasuk ikan khas (endemik), yaitu ikan motan (Thyninichthy polylepis).

Telah lama Danau Bakuok dijadikan sebagai sumber ikan bagi masyarakat sekitar. Khasnya, penangkapan ikan di danau ini dilakukan sekali setahun (bulan September), yang disebut dengan Ma'uwo. Periode di luar hari Ma'uwo, masyarakat dan siapa pun dilarang menangkap ikan di danau ini. Lebih tegasnya, dapat disebut Danau Bakuok sebagai Danau Larangan. Pengaturan larangan menangkap ikan, waktu penangkapan ikan, pemanfaatan hasil tangkapan ikan, dan bahkan kegiatan apa yang akan dilaksanakan di danau ini dikendalikan Pemangku Adat Kenagerian Tambang. Apabila ada yang melanggar (menangkap ikan di luar masa Ma'wuo) akan dikenakan denda 1 ekor kerbau (Amri et al., 2008).

Kondisi ini telah berlangsung puluhan bahkan ratusan tahun. Semula kegiatan ini dilaksanakan pada skala kecil, setingkat kenegerian. Seiring dengan perkembangan masyarakat, hal ini semakin maju dan dikenal luas, bahkan sampai ke luar kenegerian Tambang. Tak kalah pentingnya, bahkan telah dikembangkan menjadi ajang tahunan pesta rakyat yang dilengkapi berbagai kegiatan selain kegiatan Ma'uwo yang menjadi soko aktivitas dan dibuka oleh pejabat daerah seperti Gubernur atau Bupati. Danau Bakuok yang berlokasi Bangkinang (Riau) dapat dilihat pada Gambar 3.

\section{Pengelolaan Kawasan Suaka}

Sebagai kawasan suaka adat, Danau Bakuok tidak dijaga dengan menempatkan penjaga khusus, tetapi dijaga secara kolektif oleh masyarakat. Pada salah satu bagian danau terdapat bangunan yang menjadi tempat pelaksanaan upacara Ma'wuo, dan pada salah satu sisi danau terdapat jalan raya yang dapat dilalui kendaraan. Tidak terdapat papan nama yang mengatakan bahwa lokasi tersebut sebagai kawasan konservasi adat serta belum memiliki dasar hukum sebagai dasar penetapannya. Belum ada dokumentasi yang mengatakan batasan-batasan yang jelas Danau Bakuok serta pembagian daerah sebagai layaknya kawasan konservasi. 
Pada tahun 2004, pemerintah melakukan penaburan benih ikan (restocking) di Danau Bakuok dalam konsep culture base fisheries. Dipilihnya Danau Bakuok sebagai lokasi pelaksanaan restocking ini antara lain karena pertimbangan bahwa kawasan perairan ini telah dikelola secara baik oleh masyarakat sendiri sejak lama. Jenis ikan yang ditebar adalah ikan baung, berupa jenis ikan lokal yang telah ada dan berkembang di perairan ini. Jumlah benih ikan baung yang ditebarkan 62.500 ekor dengan ukuran 2-3 inci (Anonimus, 2004). Diharapkan masyarakat dapat meningkatkan produksi ikan perairan Danau Bakuok yang makin menurun akibat terjadinya kelebihan tangkap biota ikan dan semakin menurunnya kualitas air danau serta berubahnya struktur ekologis danau. Berdasarkan pada data Dinas Perikanan dan Kelautan, produksi yang akan dapat diperoleh culture base fisheries Danau Bakuok dengan restocking tersebut sebagai berikut dari jumlah 62.500 ekor benih ikan baung yang ditebarkan jika kelulusan hidupnya diperkirakan $50 \%$, maka diperoleh sekitar 31.250 ekor ikan baung (Dahril, 2007). Selama kurun waktu lebih kurang 1 tahun, diperkirakan pertambahan bobot ikan baung mencapai $1 \mathrm{~kg}$. Sehingga produksi yang diperoleh berjumlah $31.250 \mathrm{~kg}$. Jika harga per kg ikan baung di tempat penangkapan Rp.20.000,- secara matematis diperoleh produksi dalam bentuk uang sejumlah Rp.625.000.000,-. Sebaliknya, jika perkiraan angka kelulusan hidup ikan yang ditabur di atas angka sudah barang tentu produksinya akan lebih besar, karena angka optimis kelulusan hidup penaburan benih seperti ini lazimnya antara 60-70\%.

\section{Suaka Perikanan Jambi}

\section{Keadaan Umum}

Suaka perikanan yang ada di Propinsi Jambi sekitar 14 buah dan pada umumnya aktif sebagai daerah suaka (reservat). Suaka perikanan yang ada di daerah Jambi pada umumnya merupakan daerah rawa banjiran (Oxbow) yang banyak tumbuhan air (sekitar 20-50\%) dan mempunyai hubungan dengan sungai, di mana saat musim hujan luasannya bertambah dan saat musim kemarau perairan ini mengecil bahkan ada yang sampai kering.

Rata-rata luas dari daerah suaka perikanan ini berkisar antara 2-400 ha dengan kedalaman rata-rata sekitar 2-10 m (Tabel 3). Selain itu ada yang disebut lubuk larangan yaitu suatu wilayah tertentu yang oleh sekelompok masyarakat dengan batas-batas yang ditentukan berdasarkan pada keputusan adat, dan pada umumnya panjang lubuk larangan tersebut sekitar 200-300 m dan selebar sungai atau anak sungai yang ada. Lubuk larangan ini pada waktu tertentu ditutup untuk tidak melakukan kegiatan penangkapan ikan atau kegiatan apapun dan akan dibuka kembali untuk dilakukan penangkapan ikan secara bersama-sama. Kegiatan pembukaan lubuk larangan dilakukan maksimal 2 kali dalam setahun atau berdasarkan pada keputusan adat, jika ada yang melanggar akan dikenakan sanksi berupa denda hewan, beras, atau uang sesuai takaran kesalahannya. Pelarangan ini diberlakukan bagi komunitas kepemilikan wilayah setempat.

Memang secara legalitas sumpah adat ini tidak mengikat, namun sangat berpengaruh pada masyarakat, karena larangan penangkapan ataupun perusakkan sumber daya hayati sangat ditakuti oleh masyarakat setempat, apalagi masyarakat di luar wilayah tersebut. Lubuk larangan ini merupakan salah satu bentuk kegiatan konservasi walaupun tidak secara permanen dilakukan tapi pada dasarnya masyarakat menyadari bagaimana penting untuk menjaga kelestarian sumber daya ikan yang ada agar berkesinambungan. Di Propinsi Jambi ada sekitar 35 buah lubuk larangan, dan ini tersebar di beberapa kabupaten atau kota yang mempunyai sungai atau anak sungai.

Vegetasi air dominan di beberapa daerah suaka yang ada di Propinsi Jambi Azolla piñata, Ceratophyllum sp., Cyperus malaocencis, Ipomoea aquatica, Lemna sp., Ludwigia palustris, Neptunia plema, Hydrilla verticilata, dan rumput tingkat tinggi.

Jenis-jenis ikan yang ditemukan di daerah suaka perikanan pada umumnya adalah jenis ikan rawa antara lain ikan betok, serandang (Channa pleuropthalmus), gabus (Channa striata), bujuk (Channa lucius), jelawat (Leptobarbus hoeveni), kepras (Cyclocheillichthys apogon), lampan atau kapiak (Barbodes schwanenfeldi), lambak muncung (Labiobarbus ocellatus), lambak pipih (Thynnichthys polylepis), patin, baung, lais (Kryptopterus macrocephalus), toman (Channa micropeltes), lele, tembakang (Helestoma temincki), seluang (Rasbora sp.), sepat siam (Trichogaster trichopterus), sepat rawa (Trichogastersp.), udang galah (Macrobrachium sp.), puyau (Osteochillus hasselti), sanggiringan (Mystus microcanthus), betutu, arwana (Scleropages spp.), gurame (Osphronemus goramy), nilem (Osteochillus haselti), sebarau (Hampala macrolepidota), medik (Osteochilus waandersii), parang (Macrochirichthys macrochirus), barau (Hampala macrolepidota), semah (Labeobarbus spp.), repang (Puntioplites waandersiti), balido 
Tabel 3. Keadaan suaka perikanan (reservat) di Propinsi Jambi

\begin{tabular}{|c|c|c|c|c|c|c|}
\hline No. & Nama suaka & $\begin{array}{c}\text { Lokasi } \\
\text { Kabupaten } \\
\end{array}$ & Tipe & $\begin{array}{l}\text { Luas } \\
\text { (ha) }\end{array}$ & $\begin{array}{c}\text { Kedalaman } \\
(\mathrm{m})\end{array}$ & Dukungan SK \\
\hline 1. & Danau Arang-Arang & Muara Jambi & Rawa & 32 & $3-4$ & $\begin{array}{l}\text { SK Bupati TK II Muara Jambi } \\
\text { No. } 271 \text { Tahun } 2003\end{array}$ \\
\hline 2. & Danau Mahligai & Muara Jambi & Rawa & 56 & $3-5$ & $\begin{array}{l}\text { SK Bupati TK II Batanghari } \\
\text { No.362 Tahun } 1996\end{array}$ \\
\hline 3. & Danau Teluk Kanali & Kota Jambi & Rawa & 2 & $1-3$ & $\begin{array}{l}\text { SK Walikota TK II Jambi } \\
\text { No.523 Tahun } 1993\end{array}$ \\
\hline 4. & Danau Teluk & Kota Jambi & Rawa & 10 & $2-6$ & SK Kadinas Propinsi Jambi \\
\hline 5. & Danau Embat & Batanghari & Rawa & - & $3-7$ & Belum di SK-kan \\
\hline 6. & Danau Napal Sisik & Batanghari & Rawa & 3 & $2-3$ & $\begin{array}{l}\text { SK Bupati Batanghari } \\
\text { No.189 Tahun } 2004\end{array}$ \\
\hline 7. & Danau Sigombak & Tebo & Rawa & & $2-8$ & $\begin{array}{l}\text { SK Kepala Dinas Propinsi } \\
\text { Jambi }\end{array}$ \\
\hline 8. & L. Teluk Kayu Putih & Tebo & Sungai & 0,5 & $2-10$ & $\begin{array}{l}\text { SK Bupati Bungo Tebo } \\
\text { No.204 Tahun } 1997\end{array}$ \\
\hline 9. & L. Manik & Bungo & Sungai & - & $2-7$ & $\begin{array}{l}\text { SK Bupati Bungo } \\
\text { No.380 Tahun } 2004\end{array}$ \\
\hline 10. & L. Bt Taman Ciri & Merangin & Sungai & 2,5 & $2-4$ & $\begin{array}{l}\text { SK Bupati Sarko } \\
\text { No.135 Tahun } 2004\end{array}$ \\
\hline 11. & L. Sahap & Kerinci & Sungai & 0,4 & $7-9$ & $\begin{array}{l}\text { SK Bupati Kerinci } \\
\text { No.141 Tahun } 1992\end{array}$ \\
\hline 12. & L. Ujung Tanjung & Merangin & Sungai & - & $4-8$ & Belum ada SK \\
\hline 13. & $\begin{array}{l}\text { Masumai } \\
\text { L. Gandeng Duo }\end{array}$ & Bungo & Sungai & & & SK Bupati Kabupaten Bungo \\
\hline 14. & $\begin{array}{l}\text { Rantai Keloyang } \\
\text { Tuo Lubuk Mangkuang }\end{array}$ & Bungo & Sungai & & & Belum ada SK \\
\hline
\end{tabular}
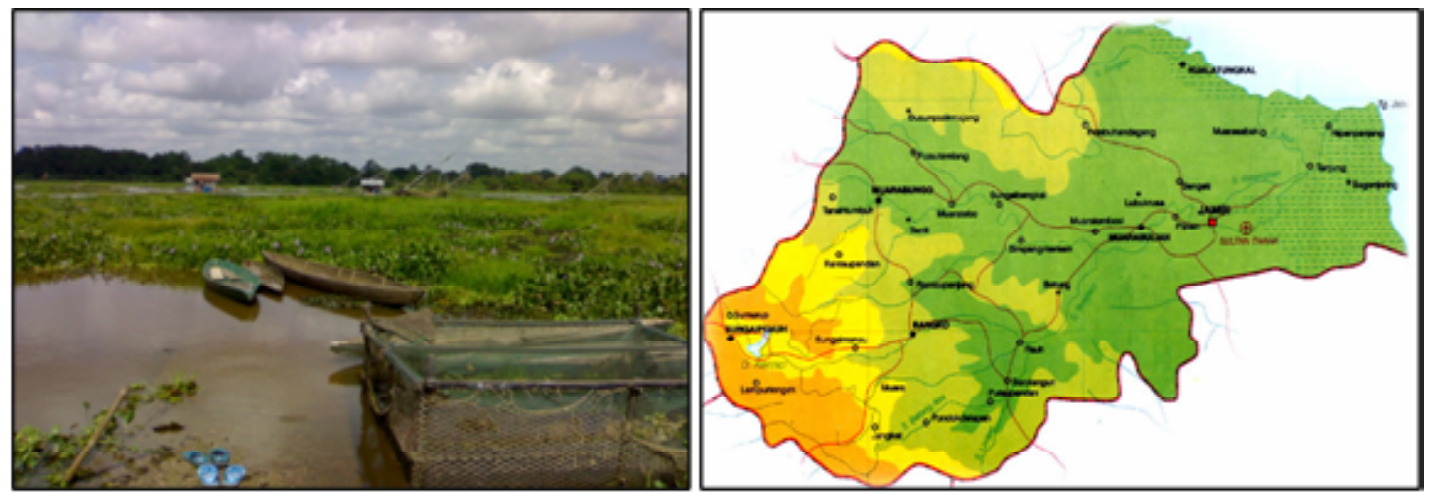

Gambar 4. Danau Teluk salah satu kawasan konservasi di Jambi.

(Chitala lopis), dan juaro (Pangasius polyuranodon). Pemandangan salah satu kawasan konservasi Danau Teluk di Jambi dapat dilihat pada Gambar 4.

\section{Kondisi Suaka Perikanan}

Suaka perikanan yang ada di Propinsi Jambi keadaannya berbeda dengan yang ada di wilayah Kalimantan, Suaka perikanan yang ada pada umumnya sudah menyesuaikan dengan aturan yang ada dan petunjuk pelaksanaan suaka perikanan (reservat) yaitu membagi 3 daerah dalam suaka perikanan yaitu daerah inti, penyangga, dan ekonomi. Dengan adanya daerah-daerah ini akan memperjelas keberadaan suaka perikanan dengan fungsi-fungsi yang ada. Namun keadaan ini tidak semuanya berjalan sesuai dengan aturan yang ada, bahkan ada beberapa suaka perikanan tidak jelas batas-batas tersebut sehingaa banyak nelayan yang melakukan penangkapan di daerah inti dari suaka perikanan yang telah ditetapkan. Selain itu terlihat banyak di daerah suaka dilakukan banyak kegiatan usaha budi daya ikan dalam karamba maupun dalam hampang.

Di lain pihak, keadaan suaka perikanan yang ada terutama di danau-danau pada umumnya sudah kurang sesuai lagi dengan ekosistem yang ada. Hal ini karena perairan yang dijadikan suaka keadaan 
kurang mendukung terutama banyaknya tumbuhan air, keadaan airnya semakin surut saat musim kering, keadaan kualitas airnya kurang layak, dan masyarakat nelayannya kurang mendukung keberadaan suaka perikanan yaitu dengan melakukan penangkapan di daerah inti yang telah ditetapkan dengan menggunakan alat anco, jala tancap, dan alat tangkap lainnya serta tidak adanya pengawasan dari dinas terkait atau aparat desa. Suaka Perikanan di wilayah Propinsi Jambi pada umumnya sudah memiliki ketetapan aturan yang dikeluarkan oleh pemerintah setempat berupa Surat Keputusan baik dari Gubernur, Bupati, Walikota, dan Kepala Dinas Perikanan Propinsi.

Sedangkan untuk lubuk larangan pada dasarnya merupakan suatu bentuk konservasi yang dibuat melalui aturan adat setempat (dalam suatu dusun atau desa). Kondisi lubuk larangan ini pada umumnya baik, karena diawasi oleh pemuka desa atau dusun dan keberadaannya di sekitar wilayah tempat tinggal sekelompok masyarakat yang memanfaatkannya. Keberadaan lubuk larangan ini timbul, karena kelompok masyarakat di sekitarnya merasa untuk melindungi sumber daya yang ada di sekitar mereka, dan dapat dimanfaatkan secara berkesinambungan (tidak punah). Aturan lubuk larangan ini cukup jelas, karena diawasi oleh pemuka desa atau agama dan barang siapa yang melanggar aturan adat ini akan dikenakan sanksi, dan keadaan ini tetap berlaku di masyarakat sampai saat ini. Lubuk-lubuk larangan yang ada dapat ditingkatkan secara konservasi menjadi daerah suaka jika masyarakat menginginkan dan ada sesuatu hal yang memungkinkan untuk menutup daerah tersebut untuk melakukan penangkapan atau kegiatan apapun, seperti daerah pemijahan ikan (spawning ground), daerah pembesaran (nurserry ground), atau hal-hal tertentu. Penutupan daerah lubuk larangan menjadi daerah suaka juga berdasarkan pada persetujuan pemuka adat atau desa setempat dengan dinas perikanan setempat.

Dengan melihat keadaan suaka perikanan yang ada di wilayah Propinsi Jambi, hal ini menunjukkan bahwa suaka perikanan yang ada di wilayah ini merupakan suaka konservasi dengan pembagian daerah sesuai ketentuan untuk suaka perikanan. Akan tetapi sejauh ini pembatasan daerah-daerah ini tidak jelas, sehingga banyak kegiatan perikanan seperti penangkapan ikan dilakukan di daerah inti yang tertutup untuk kegiatan perikanan apapun. Di lain pihak, tidak adanya pengawasan di sekitar lokasi suaka oleh petugas dinas perikanan ataupun aparat desa, sehingga masyarakat sekitar atau nelayan dapat melakukan kegiatan apapun di lokasi suaka tersebut, walaupun sudah ada papan pengumuman untuk melarang melakukan penangkapan.

\section{KESIMPULAN}

1. Sampai saat ini daerah suaka perikanan yang resmi ditetapkan oleh pemerintah setempat belum ada, sementara daerah calon suaka perikanan yang diproyeksikan sudah ditetapkan. Penetapan calon suaka untuk saat ini berdasarkan pada hukum atau kesepakatan adat. Di daerah tertentu seperti Jambi dan Riau ada suatu bentuk konservasi perikanan yaitu lubuk larangan yang dikelola dengan baik oleh kelompok masyarakat melalui aturan adat dan desa setempat.

2. Hukum adat di wilayah Propinsi Jambi lebih berperan dibandingkan dengan peraturan yang dikeluarkan oleh Pemerintah Daerah.

3. Pada umumnya belum ada dokumen resmi yang mengatakan batas dan pembagian daerah kawasan di lokasi-lokasi suaka perikanan sebagaimana layaknya kawasan konservasi perikanan.

4. Pengawasan dan pengelolaan danau dilakukan oleh masyarakat adat dengan sistem penjagaan kolektif.

5. Aspek konservasi lainnya berupa pemacuan stok ikan tahunan serta peran organisasi masyarakat sebagai pengawas dan perlindungan sumber daya ikan di beberapa lokasi suaka perikanan sudah berjalan dengan baik.

\section{PERSANTUNAN}

Kegiatan dari hasil riset kebijakan pemanfaatan dan konservasi keanekaragaman hayati ikan, T. A. 2007 di Pusat Riset Perikanan Tangkap, AncolJakarta. Penulis mengucapkan terima kasih kepada Drs. Dadiek Prasetyo (alm.) sebagai salah anggota tim peneliti atas kontribusinya dalam penyusunan paper ini, semoga sumbangan pemikiran dan dedikasinya menjadi amalan baik dan mendapat balasan yang setimpal di sisi-Nya. Amien.

\section{DAFTAR PUSTAKA}

Anonimus. 2003. Perikanan Perairan Danau. Dinas Perikanan dan Kelautan Propinsi Sumatera Utara. Medan.

.2004. Undang-Undang RI No.31 Tahun 2004 tentang Perikanan. 
. 2004. Culture Base Fisheries Danau Bakuok Kabupaten Kampar. Artikel Harian Riau Tribune. Edisi 24 Nopember.

Amri, K. \& D. Prasetyo. 2008. Pengelolaan suaka perikanan Danau Bakuok, Kabupaten Kampar Riau. BAWAL Widya Riset Perikanan Tangkap. 2 (3): 2009. p. 109-114.

Dahril, T. 2007. Kebijakan Pembangunan Perikanan dan Kelautan di Propinsi Riau. Dinas Perikanan dan Kelautan Propinsi Riau. Materi Presentasi.

Dinas Perikanan dan Kelautan Jambi. 2007. Laporan Tahunan Dinas Perikanan dan Kelautan Jambi.

Hoggarth, D. \& A. D. Utomo. 1994. The fisheries ecology of the lubuk lampam river in South Sumatera, Indonesia. International Journal Fisheries Reserach. Elsevier Netherland. p. 192213.

Hartoto, D. I., A. S. Sarnita, D. S. Sjafei, A. Satya, Y. Syawal, Sulastri, M. M. Kamal, \& Y. Siddik. 1998. Kriteria Evaluasi Suaka Perikanan Perairan Darat. Lembaga IImu Pengetahuan Indonesia. Pusat Penelitian dan Pengembangan Limnologi.

Kartamihardja, E. S. 1987. Potensi produksi dan pengelolaan perikanan di Danau Toba, Sumatera Utara. Buletin Penelitian Perikanan Darat. 6 (1).
Krismono, A. S. N. \& A. S. Sarnita. 2003. Penilaian ulang lima lokasi suaka perikanan di Danau Toba berdasarkan kualitas air dan parameter perikanan lainnya. Jurnal Penelitian Perikanan Indonesia. 9 (3): p. 1-11.

Ruttner, F. 1930. Hydrographische und hydrochemishe Beobachtungen auf Java, Sumatera und Bali. In A. Thienemann. Archiv fûr hydrobiologie. Organ Der Internationalen Fûr Theoretische und Angewandte Limnologie. Supplement-Band VIII. E. Schweizerbart'sche Verlagsbuchhandlung (Erwin Nägele) G.m.b.H. Stuttgart. p. 196-454.

Sarnita, A., W. Ismail, \& N. Listyanto. 1995. Rehabilitasi populasi ikan di Sungai Musi melalui teknologi pengelolaan reservat perikanan. Prosiding Seminar Penelitian Perairan Umum. Pusat Penelitian dan Pengembangan Perikanan. Jakarta. p. 23-44.

Sarnita, A. S. 1999. Introduction and stocking of freshwater fishes into inland waters of Indonesia. In W. I. T. van Densen \& M. J. Morris (eds). Fish and Fisheries of Lakes and Reservoirs in Southeast Asia and Africa. Westbury Publishing. Otley. UK. p. 143-150.

Tjahjo, D. W. H., A. S. Nastiti, K. Purnomo, E. S. Kartamihardja, \& A. S. Sarnita. 1998. Potensi sumber daya perikanan di Danau Toba, Sumatera Utara. J.Lit.Perikan.Ind. 4 (1): p. 1-12. 